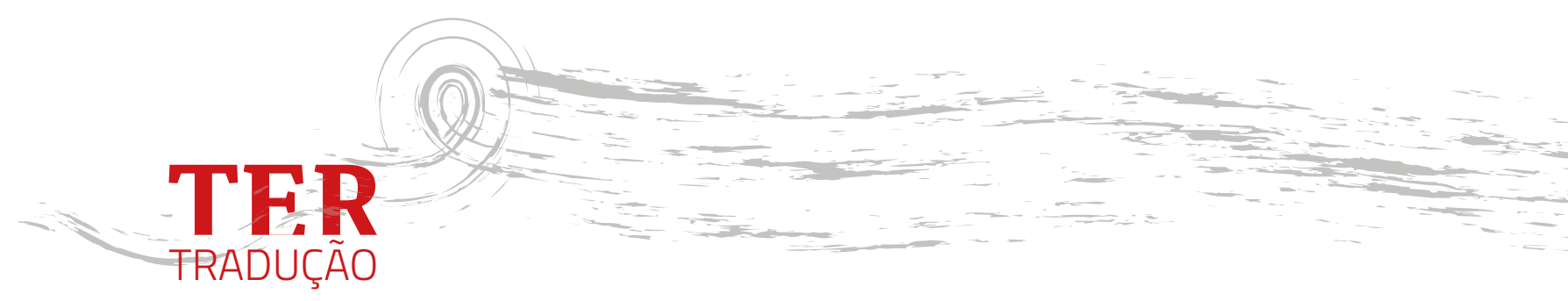

University of Cambridge, Reino Unido.

MARILYN STRATHERN

tradução

BRUNO PEREIRA DE ARAUJO

revisão técnica

SYLVIA CAIUBY NOVAES

\title{
GÊNERO \\ DE UMA PERNA SÓ ${ }^{1}$
}

\section{RESUMO}

Neste artigo, Marilyn Strathern busca construir uma teoria visual melanésia focando nos efeitos de tipos particulares de exibição, tais como práticas que acompanham iniciações ou trocas cerimoniais, tendo em vista que nesses contextos há um investimento na manipulação das formas por parte das pessoas. A autora busca responder, a partir dos matérias melanésios, o que seria ver para essas pessoas e que tipo de corpo é engendrado por uma prática visual em que o que se vê é deliberadamente tornado incompleto.

\section{ABSTRACT}

In this article, Marilyn Strathern seeks to construct a Melanesian visual theory focusing on the effects of particular types of display, such as practices accompanying initiations or ceremonial exchanges, given that in these contexts there is an investment in the manipulation of forms by people. The author seeks to answer, from the Melanesian material, what it would be like to see these people and what kind of body is engendered by a visual practice in which what one sees is deliberately rendered incomplete.

1. STRATHERN, Marilyn. 1993. One-legged gender. Visual Anthropology Review, vol. 9: 42-51. Publicado pela American Anthropological Association. 
Entre as inúmeras contribuições do recente livro dos Hansons (1990) sobre arte e identidade na Oceania, três induziram a este exercício. Uma é o lembrete de Schwimmer de que Lévi-Strauss referia-se à arte como miniaturização; a segunda é a breve referência dos Hansons às figuras maori que, colocadas nos lintéis das portas, parecem recompor os traços do corpo em novas formas; a terceira é um ensaio de Smidt (1990) acerca das figuras de uma perna só da área do Middle Ramu (Kominimung) na Papua-Nova Guiné. Essa última é uma apresentação estranha, mas ainda assim evidente de uma forma corporal - Smidt registra o gesto espontâneo de um homem que se converteu em uma figura de uma só perna para mostrar-lhe o que aquilo tudo significava.

Entre os desafios que a Papua-Nova Guiné e outras culturas melanésias apresentam para a interpretação visual, a manipulação das formas pelas pessoas também induziu este exercício. 0 interlocutor papuásio de Smidt vestiu-se para o papel com considerável extravagância, enfiando a ponta de uma veste alongada em sua boca e golpeando um novato invisível com uma figura de uma perna só em suas mãos. Essa era uma exibição. Uma tensão que corre pelas exibições melanésias é a tensão entre o que é ocultado e o que é revelado. 0 convite para "ver" é um convite para testemunhar o aparecimento de uma forma específica e, nesse sentido, elicitá-la. A testemunha individual é inevitavelmente colocada pelo performer na posição de ver apenas o que é revelado; é como se a testemunha "visse" um lado do performer. De fato, nas histórias que as pessoas nas Terras Altas da Papua-Nova Guiné contam às vezes, criaturas de um lado só, com costas mas sem frente, ou com um olho em vez de com dois, em geral passam rapidamente diante da visão humana.

Entre os muitos requintes de cunho analítico que inspiram o recente interesse antropológico pela estética, nós não devemos esquecer de que a visão é incorporada [embodied]. Nesse caso, em que tipos de corpo os olhos estão dispostos? Eu coloco a questão como um comentário acerca dos pressupostos modernistas que perpassam os melhores esforços para evitar as armadilhas do representacionismo e do construtivismo.

Não basta simplesmente inserir uma infinita sofisticação acerca do deslocamento do conhecimento em lugar de modelos autoritários, tampouco reclamar sobre a desincorporação [disembodiment] do conhecimento enquanto se imagina que tudo o que está em jogo é uma maior reflexividade. Nichols $(1991,34)$ se refere à cegueira corporal que aflige uma narração fílmica despersonalizada. É uma insistência na incorporação que marca certas indagações feministas. Às vezes, porém, esses discursos parecem compartilhar, em vez de obviar, a obsessão representacionista anterior em descobrir fatos sobre o mundo. A 
incorporação é extraída do texto, uma influência escondida é tornada explícita e a análise nos convida a ver o que não víamos antes. Frequentemente, tais apelos à visão servem como metáforas para ampliar a consciência. 0 que, nesse caso, faz diante de provocações deliberadas à visão? A questão seria particularmente perspicaz quando, sendo mostrado algo, a(o) antropóloga(o) também fosse forçada(o) a ver com um olho apenas - na medida em que a própria visão é, no contexto da exibição melanésia², tornada de um olho só.

Eu foco nos efeitos de tipos particulares de exibição, tais como práticas que acompanham iniciações ou trocas cerimoniais, embora suspeite que 0 argumento poderia se sustentar abrangendo toda a vida social melanésia. Exibições sempre selecionam, a partir de múltiplas possibilidades, uma única que será tornada evidente, e se vê apenas o que é revelado. 0 que está oculto é deliberadamente ocultado, ainda que o segredo possa também ser trivial: com o outro olho, a pessoa simplesmente veria o outro lado. Esse fato sobre a visão apenas é evidenciado por meio da incorporação. Como consequência, não há nada nesse jogo visual para ser "descoberto" sobre a incorporação, uma vez que o corpo é o seu meio [medium] e é deliberadamente incompleto.

Então, o que é esse corpo-de-um-lado-só que é imaginado como o único tipo de corpo que pode ser visto, já que é o único que elicita a visão? É um corpo personificado: uma pessoa somente vê tal forma como um resultado das relações com outros. É também um corpo com gênero: um homem ou mulher somente o vê como masculino ou feminino.

\section{DE UMA PERNA SÓ}

Um postulado da crítica feminista é que é um erro imaginar que sabemos o que é um corpo quando vemos um. Muito esforço foi destinado a desnaturalizar o "corpo" recebido do discurso euro-americano, e o que é trazido à vista é a trivialização ou o engrandecimento da identidade sexual (o esforço está em como ficar "entre" a obsessão por gênero e a cegueira de gênero). Mas, ao desnaturalizar o gênero do corpo, talvez devêssemos também desnaturalizar a composição corporal. Eu quero dizer a disposição do torso, dos membros e dos órgãos. Não importa quão transitórias pareçam ser as estratégias analíticas contemporâneas ao ver ou não o gênero, suas conclusões podem já estar

\footnotetext{
2. E nos comentários das pessoas sobre si próprias. Biersack (1990, 78-79; 1991, 260) observa que os paiela das Terras Altas da Papua-Nova Guiné se contrastam com o onisciente sol que tudo vê, na frase: "Nós temos um olho só, o sol tem dois". o sol inclui todos em sua visão e é, ele próprio, desse modo, sem corpo (Biersack 1991, 260). O interesse nesse ponto se evidenciará no argumento que segue.
} 
comprometidas pelas naturalizações modernistas e euro-americanas que localizam a principal fonte da diferença sexual em uma parte do corpo. Símbolos sexuais tendem a ser interpretados como fálicos ou vúlvicos/uterinos antes de ser interpretados como qualquer outra coisa. o problema não é que euro-americanos não possam imaginar quase todas as partes do corpo como genitalizadas, mas que a tendência seja de que apenas os genitais mudem de lugar em sua imaginação. Melanésios apresentam o gênero por refigurações das quais os genitais são apenas uma parte - membros, órgãos e interiores, inclusive olhos, podem todos mudar de lugar. Essa figuração pode ser criada tanto entre várias pessoas quanto em apenas uma.

Foi pura inspiração de Smidt (1990) chamar as figuras kominimung de "de uma perna só". Contudo, eu suspeito que isso teve razões naturalísticas e composicionais: essas figuras entalhadas em madeira com uma cabeça e torso do qual se estende um único membro/órgão poderiam ser colocadas de pé como se essa extensão fosse sua (única) perna. De qualquer modo, o entalhador cujas atividades Smidt acompanhou parece ter sustentado sua inferência, dividindo a escultura em cabeça, torso e perna.

Mas, então, como Forge (1965) observou sobre as casas de homens Abelam, é correto afirmar que a viga horizontal da casa é tratada como se fosse um falo... Porém, o que é um falo? Nós poderíamos nos perguntar o que é uma perna.

Em outro contexto, Forge $(1970,290)$ comenta sobre o fato de que se espera que a "arte" tenha um efeito:

Uma das muitas funções do sistema de iniciação [dos Abelam], com sua exposição repetitiva dos novatos a grandes quantidades de arte, é - eu sugeriria - ensinar os jovens rapazes a ver a arte, não de modo que eles possam conscientemente interpretála, mas que eles sejam diretamente afetados por ela. (tradução nossa)

o entusiasmado kominimung que mostrou a Smidt o que as figuras de uma só perna significavam estava mostrando a ele o que elas podiam fazer. Essas figuras de madeira chutavam. Em um momento no curso da iniciação masculina, novatos são reunidos e cutucados com elas. Smidt (1990) tem uma fotografia demonstrativa (Figura 1) de um homem em vestes comuns batendo tal figura - "perna" estendida - nas costas de um suposto novato. A figura segurada por um golpeia o outro. Em outra página (Smidt 1990) está a fotografia (Figura 2) do entusiasta que se vestiu, suas duas próprias pernas firmemente afastadas uma da outra. 
Entre outras decorações, no seu peito há uma bolsa de cordas com seios femininos; mamilos também são pintados na figura de madeira. Nessa forma, o performer torna visível um poderoso tambaran (espírito ancestral), assim como o faz a própria figura de madeira. A figura é segurada de modo alinhado à cabeça e ao peito do homem, projetando-se para baixo e para fora. De fato, a fotografia chama a atenção para a maneira que o gesto é, por assim dizer, repetido através da longa e estreita veste que forma um laço entre as pernas do homem e é levado à sua boca. Visualmente, porém, não há direção para esse ornamento - ele poderia tanto estar saindo da boca quanto entrando nela. Do mesmo modo, a figura que é segurada por um corpo também encontra seu alvo num corpo: o novato expõe suas costas (novatos podem ser golpeados nas costas ou no peito, mas arquetipicamente o são nas costas) para ser chutadas. Portanto, a figura na realidade aponta para ambas as direções: para o corpo que a projeta e para o corpo que a convida.

Em outro lugar no mesmo volume, os Hansons (1990) se apoiam em uma análise oferecida por Jackson (1972) para avançar um argumento sobre a estranha composição dos entalhes dos lintéis maori em cima dos vãos de entrada das casas. 0 que é desarticulado é em seguida combinado em uma nova justaposição de elementos. Assim, o corpo é reagregado, do mesmo modo que a pessoa, entrando e saindo da casa, é redefinida por suas ações. Tais decomposição e recomposição "pode-se considerar que representam o papel dual dos indivíduos na sociedade - como uma figura tribal, pública, e uma figura doméstica, privada" (Hanson 1990, 192, tradução nossa). No caso maori, o corpo é recriado dentro do espaço circunscrito da estrutura da porta ${ }^{3}$. Se o exemplo melanésio dos Kominimung é também a recriação de um corpo, não há tal confinamento arquitetônico. Todavia, a figura de uma perna só, projetando para fora da cabeça/peito ou golpeada nas costas, não é estendida tampouco pelo espaço. Antes, ela é especificamente destinada a uma outra pessoa. Mais de uma pessoa é necessária para essa recomposição. Eu infiro que a composição é de relações e que as relações contêm e criam uma diferença interna; iniciador e novato são diferenciados pelo ato de chutar.

3. Embora a forma que o corpo recomposto assume (uma figura de dois lados, ou "cindida") seja encontrada em uma variedade de contextos, não apenas nas entradas, e possa também estar livre de qualquer suporte. 

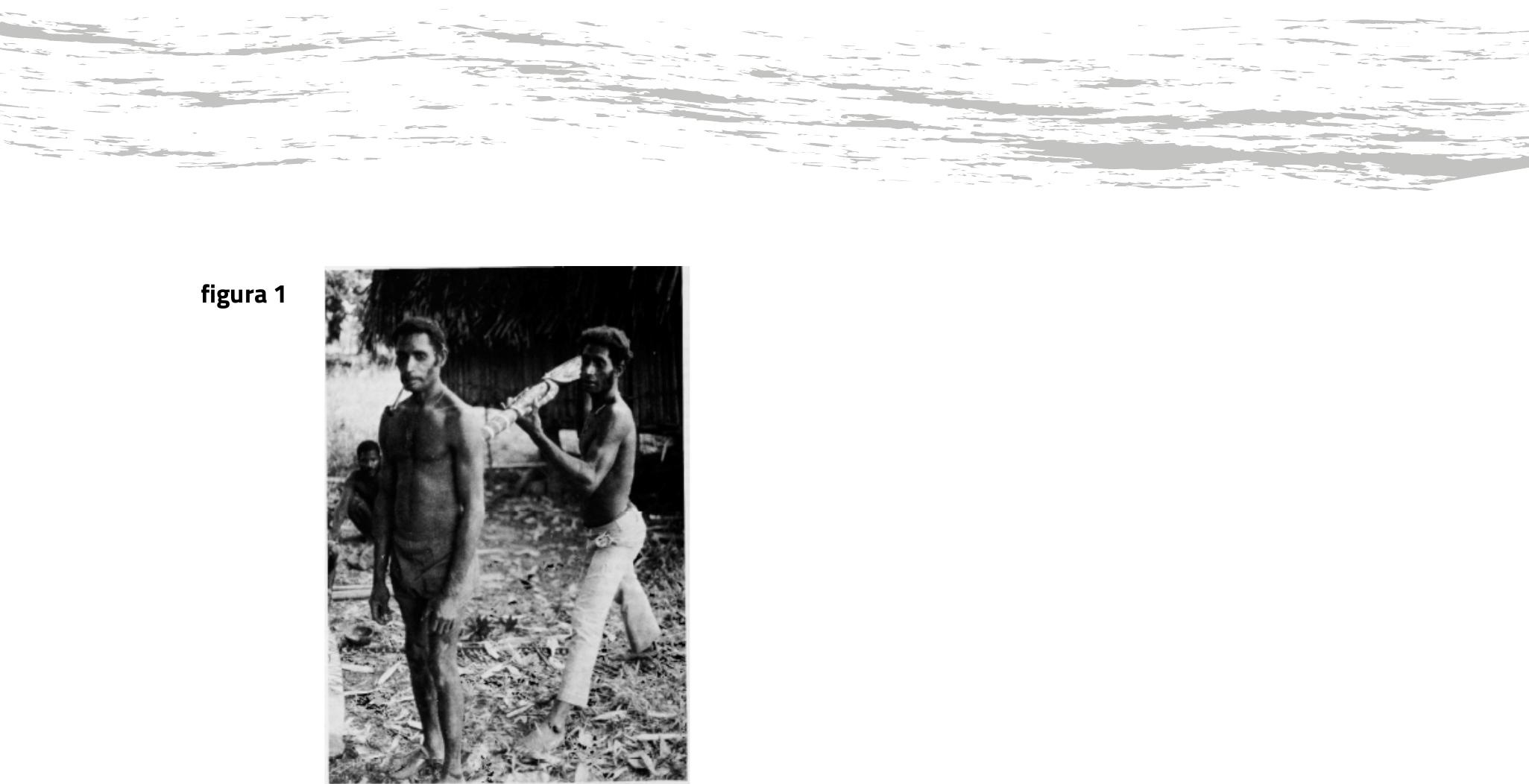

Se novato e iniciador são, para olhos naturalísticos, evidentemente duas pessoas, eu quero sugerir que o duo também está presente em apenas uma. o homem que segura a figura de uma só perna, paralela ao seu corpo, está unido a ela, no sentido de que ambos exibem tambaran para o novato. No entanto, enquanto euro-americanos teriam poucos problemas em considerar o homem e sua figura de madeira como um tipo de par, poderiam ter menos facilidade em ver que a própria figura de madeira, com sua cabeça e seu torso e o órgão que se estende dele, é também um conjunto de relações. Mas, de fato, qualquer figura singular é sempre uma composição. 0 homem que prende com força a veste que cobre seu pênis nos dentes transmite isso. Como os monstros ancestrais que podem aparecer em outros lugares da Papua-Nova Guiné, ora engolindo, ora regurgitando (iniciados), as pessoas não podem agir - sobre si mesmas ou sobre outras - sem instanciar a diferença entre elas.

figura 2

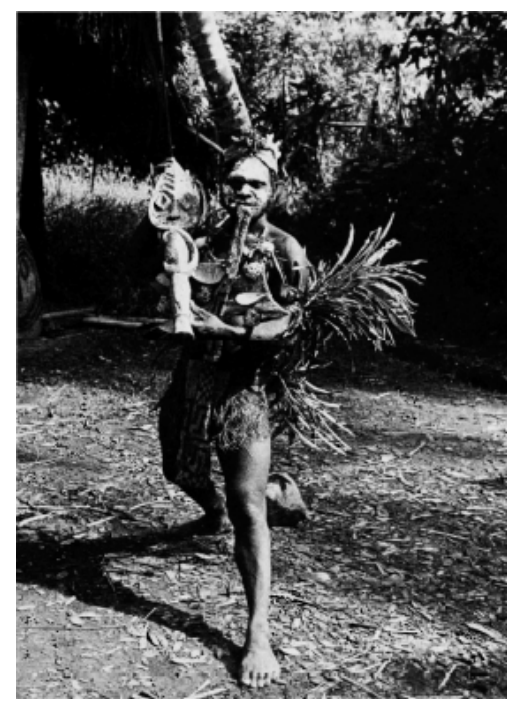


Portanto, se a diferenciação de pessoas segue aqui a estética de gênero melanésia, essas figuras não são de mesmo-sexo, mas andróginas ${ }^{4}$ ? (Os performers, como Smidt $(1990,34)$ nota, exibem elementos tanto masculinos quanto femininos em suas vestimentas.) De fato, há um sentido em que todos os objetos são andróginos (cf. Mackenzie, 1991), na medida em que sua personificação requer que eles sejam compostos ${ }^{5}$. Eu suspeito que o novato e os iniciadores kominimung adquiram gênero pelas ações que um realiza no outro, assim como o engolidordepênis/regurgitadordecrianças recapitula a genderização [gendering] de qualquer atividade extensiva.

É completamente consoante com o que é conhecido em outras partes da Papua-Nova Guiné sugerir que a própria atividade extensiva pode ser imaginada em termos de receber atenção sexual ou dar à luz - incluindo relações entre parceiros em troca de dádivas, que podem permanecer momentaneamente masculinos ou femininos um para o outro. Eu digo "extensiva" na medida em que um corpo assimila/gera um outro corpo. São juntos que os corpos formam uma única figura andrógina; e, visto que a capacidade de formar tal figura também está presente no corpo singular, esse corpo é inevitavelmente andrógino também. Não importa quantas pessoas você vê: cada uma é uma composição de pessoas.

Mas você não vê a composição. Isto é, como um(a) observadora(o), você não vê ambos os gêneros ao mesmo tempo; você "vê" apenas um, pois é isso que significa "ser feito para ver". Deixe-me explicar essa observação.

Veja o novato. O novato pode eventualmente se equiparar ao homem que segura a figura de uma perna só, pois ele está sendo transformado no tipo de homem que pode fazer exatamente aquilo a novatos. Ao final da sequência de iniciação, em que o antigo novato foi transformado em uma pessoa casável, ele aparece decorado "da mesma forma que as figuras de uma perna só e os performers tambaran" (Smidt 1990, 31, tradução nossa). Mas, no momento do impacto, o novato-iniciado está em uma posição apenas. Ele vê, isto é, "sente" o golpe, é receptivo a ele e só pode ser receptivo. Ele é o "outro lado" do que uma figura de uma perna só pode fazer. o receptor que sente a figura de uma perna só, ao senti-la ele

\footnotetext{
4. Por estética, Marilyn se refere ao modo pelo qual as relações assumem uma forma convencional que evidencia que elas foram ativadas e têm algum efeito. No caso melanésio, essas formas são expressas em termos de gênero, podendo ser de "mesmo-sexo" ou de "sexo-cruzado", que são estados alternados que precisam ser produzidos a partir de um fundo generalizado de androginia. [N.T.]

5. O performer que segura a figura de uma só perna pode ser referido como uma "criança" em relação aos guardiões masculinos e femininos do tambaran que o acompanham; um quarto ator é o "amigo" do tambaran. Sobre a androginia de crianças, ver, por exemplo, Strathern (1992).
} 
a manda "de volta" ao homem que a está golpeando contra ele. O novato é nesse sentido um espectador. Ele responde àquilo que lhe é mostrado.

o kominimung que se vestiu para mostrar para Smidt como fica um homem segurando uma figura de uma só perna poderia imaginar que ele estava colocando o espectador na posição de receptor, como se a câmera pudesse lhe responder. Agora estando em um lado, o(a) espectador(a) pode ver somente o "outro" lado que está sendo apresentado: ela/ele não vê a si própria(o), pois ela/ele é forçada(o) a adotar a perspectiva (a visão) de alguma outra pessoa. 0 que os espectadores veem é uma figura andrógina na forma de mesmo-sexo. Smidt infere que as figuras de uma só perna conotam a fertilidade masculina. Este é o lado masculino: os homens criam uma versão masculina de uma figura composta de elementos tanto masculinos quanto femininos.

Portanto, o que você vê nessa fotografia é uma versão inteira masculina de uma figura que em sua composição é andrógina. Mas não se supõe que você veja a composição, pois é a partir das relações compósitas que vem a singular forma-para-ser-vista. E, já que é o espectador que elicita a aparência da forma singular, ele é parte da composição que não está disponível ao olhar.

Então, o que é uma perna? Talvez a perna de uma figura kominimung de uma perna só seja um corpo estendido. É tanto um órgão quanto um produto, poderíamos dizer, assim como as conchas que circulam nas trocas nas Terras Altas da Papua-Nova Guiné. E a extensão, que é tanto produto de um órgão quanto corpo, pode ser percebida como pertencendo a ou vindo de um corpo que é tanto masculino quanto feminino. Porque estar em um estado estendido significa que, ao ser destacado de um corpo, o órgão/produto é depositado em um outro. Não estendido, ele permanece parte de uma composição andrógina que não pode ser sentida ou vista. Com sua potencial extensão em mente, pessoas podem dizer que o órgão/produto está ainda "escondido".

\section{GÊNERO}

A fotografia que segue (Figura 3) foi tirada em 1964 em Hagen, nas Terras Altas da Papua-Nova Guiné. Não há praticamente nenhuma mulher no plano de visão, apesar de que várias estivessem presentes. Contudo, os produtos das mulheres são evidentes: as crianças (incluindo a pequena garota no longínquo final da fila, que lança um olhar na direção da fotógrafa), as conchas de pérola Goldlip dispostas em frente à casa dos homens - muitas das quais terão chegado aos homens via suas conexões com mulheres - e as estacas de porco vazias nas quais os porcos das mulheres serão amarrados. Se crianças e porcos são reconhecidamente 
extensões de mulheres, os homens também são. Cada um deles é o filho de uma mãe e em alguma ocasião de suas vidas terão reconhecido tal fato com dádivas para a parentela matrilateral.

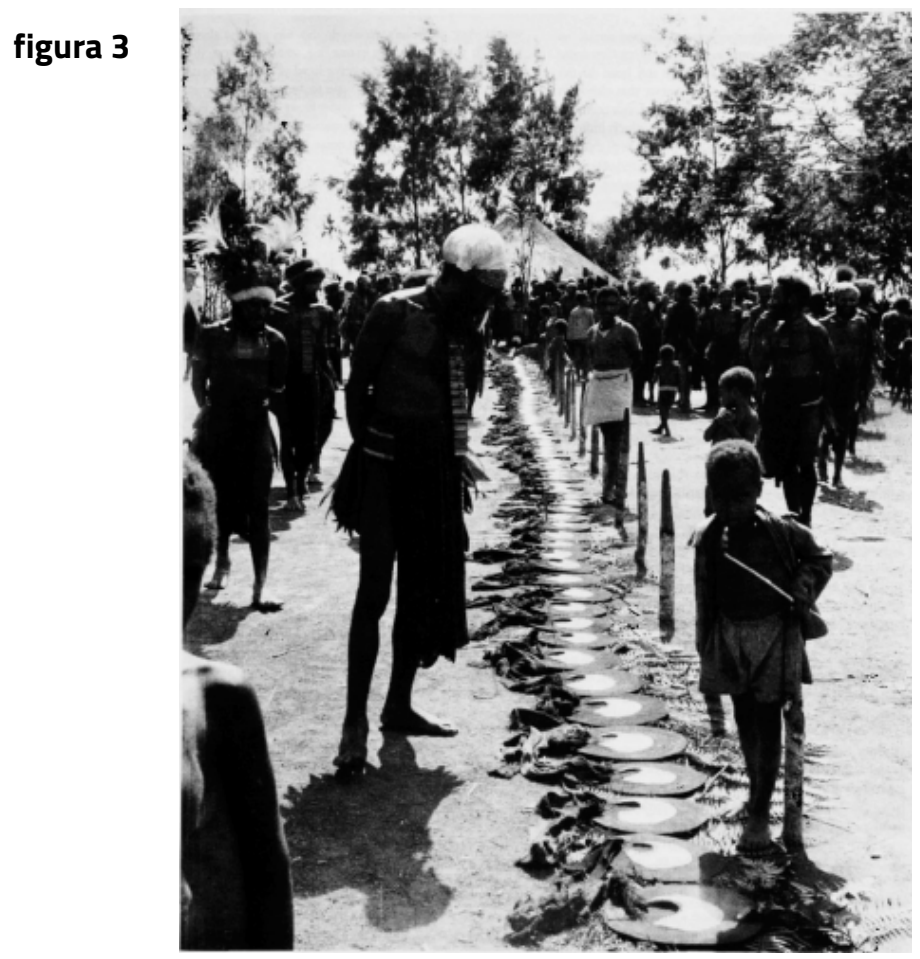

Nada disso passava pela mente da fotógrafa. Ela estava muito preocupada com a sequência de eventos. (As conchas estavam ainda sendo dispostas e ela se desviou do conjunto principal de atividades para ver a fileira que já existia.) Era a primeira apresentação pública de moka (troca cerimonial) que ela observou. Subsequentemente, ela teria consciência do fato de que as conchas circulam exclusivamente entre homens e nunca estão sob os cuidados de mulheres, exceto somente no modo mais especulativo; ela saberia que a casa dos homens ao final do espaço cerimonial é um recinto exclusivamente masculino; que, apesar de os homens não terem se decorado deliberadamente para essa ocasião, eles exibem as longas talhas [tallies] de bambu (omak), que indicam seus sucessos em trocas anteriores; e que a discussão e o cálculo seriam sobre o tipo de política com a qual os homens se preocupam - a ocasião era um pagamento compensatório entre clãs de duas tribos, dos Kawelka para os Roklaka (cf. Strathern 1971, 124). Mas, de qualquer maneira, a fotógrafa provavelmente tomou como certo que o que ela estava vendo era um assunto exclusivamente masculino. Retrospectivamente, o fato de que mulheres dificilmente apareciam na fotografia indicou uma espécie de verdade, pois mulheres eram efetivamente excluídas de papéis ativos na troca de conchas. 
Esse evento particular era uma versão relativamente menor do que era realizado em uma escala muito maior em exibições que demandam decoração formal. Em tais ocasiões, e quando os porcos estão envolvidos como produtos das mulheres, a apropriação do espaço público por homens pode ser tornada evidente pela participação das mulheres como "produtoras". Mas elas produziram os objetos, por assim dizer, não a performance: ela é criação dos homens.

Todavia, suponha que eu escolhesse ver isso como um momento em miniatura, o que está sendo miniaturizado? Eu sugiro que não é a escala da performance. Schwimmer $(1990,11)$ cita a observação de Lévi-Strauss sobre a arte; como uma redução da natureza (e, portanto, uma miniatura), arte implica abstração. Ele acrescenta que pessoas que se decoram como espíritos acabam miniaturizando os espíritos, pois elas abstraem da ideia de espírito certas qualidades ou características que podem ser tornadas visíveis. Deixe-me sugerir o que a performance de Hagen miniaturiza aqui.

No meu entendimento das práticas melanésias, uma performance é sempre uma redução: um ato singular criado a partir de relações compósitas. Ela aparece como tendo um gênero, como a exibição de qualidades de mesmo-sexo destacadas de entes andróginos. Nesse caso, por causa de toda aparência de masculinidade, vê-se apenas o lado masculino de uma versão masculina de uma composição andrógina. Eu não quero dizer que mulheres estão implicitamente presentes, embora elas estejam; eu quero dizer que o evento como um todo é uma recomposição de relações. Na verdade, tal recomposição envolve dois tipos de reduções tornadas visíveis pelo gênero das pessoas e suas extensões.

A recomposição é tornada possível, primeiro, pela divisão dos homens entre doadores e receptores: o que os homens receptores veem são outros homens na forma de doadores. Esse é o lado que os performers apresentam. Possibilidades duais são reduzidas a uma. Os mesmos homens (doadores) são receptores em outras ocasiões e, de fato, podem bem estar dando para aqueles de quem eles anteriormente receberam. As conchas também são reduzidas: elas são dispostas em uma fileira, fluindo para fora da boca ${ }^{6}$ da casa dos homens no final do terreno cerimonial. 0 evento mostra o tempo como recursivo: o que fluiu antes "para dentro" da casa agora flui "para fora" de novo. Mas o evento também, momentaneamente, destotaliza o fluxo (cf. Weiner 1991) em uma de suas duas direções, isto é, em direção aos receptores.

Em segundo lugar, múltiplas possibilidades são reduzidas a uma. O clã é sustentado por mais que suas relações com os receptores, e as conchas

6. Melpa keta, "boca", "porta", "abertura". 
em particular não são aquelas que os receptores poderiam ter dado, mas outras, ganhadas por outras relações. Porém, as diversas relações que formaram a figura compósita e andrógina de relacionamentos "a partir dos quais" as conchas vieram não podem ser vistas. Elas estão no pano de fundo: outros eventos, outras trocas, outros parceiros. As conchas instanciam a recomposição: colecionadas a partir de muitas relações, elas agora são apresentadas em uma única fileira, como a "única" dádiva que fará os receptores "verem" e "sentirem". (Quando porcos são entregues, um doador irá chutar a estaca como indicação de que uma dádiva foi dada.)

A fileira estendida é, portanto, uma figura reduzida do corpo do clã. Nós poderíamos propor que a recomposição do corpo é efeito da redução, fazendo que o corpo apareça como sua própria extensão: é como se a extensão fosse também o corpo. Assim, o corpo é apresentado por uma extensão que também é somente uma parte de si mesmo. Certamente, o clã doador aparece em uma forma estendida por meio do modo como suas conchas são trazidas "para fora", e o que as conchas masculinas parecem fazer é estender a casa dos homens. Potencialmente destacável, qualquer parte do corpo pode, portanto, ser submetida à diferenciação de outras partes. Tanto a casa quanto as conchas podem ser imaginadas como masculinas ou femininas uma em relação à outra. Desse modo, as conchas com suas bordas em ocre vermelho podem ser pensadas como pequenos embriões no útero, carregadas por suportes que mulheres outrora trançaram (cf. Clark 1991). Em tal caso, a longa fileira de conchas se estendendo da casa decompõe o clã masculino em seu corpo procriador (masculino e/ou feminino) e seus inúmeros "filhos".

De qualquer modo, o corpo procriador e o órgão/produto são replicados de várias formas. A fotografia (Figura 3) mostra que nessa ocasião, enquanto as conchas (se) estendem (d)a casa onde elas estavam, idealmente, escondidas, elas também fluem a partir de uma outra concha, aquela disposta no topo da fileira como se fosse a fonte delas todas. Cada concha individual, por sua vez, é posicionada em sua prancha [board] com sua abertura voltada para baixo, de onde saem (dificilmente visíveis na fotografia) curtas talhas [tallies] de bambu como as que os homens vestem; é aqui que os suportes para carregar as conchas são anexados. Essas replicações sugerem uma série de figuras: a porta da casa e a fileira de dádivas que saem/entram; a concha principal e as conchas que fluem; a concha montada e a talha que sai com o suporte para que a coisa toda possa ser levantada e levada embora. Todavia, isso não é uma série facilmente contida por uma escala decrescente. Veja o homem próximo à fotógrafa. Ele é uma outra figura, similar a toda e qualquer uma daquelas figuras listadas anteriormente.

Esse homem está olhando atenciosamente: quem está olhando para as conchas de pérola é uma figura com cabeça alargada de cujo pescoço 
pende um cordão de pedaços de bambu, as talhas omak que registram seu sucesso em transformações de conchas ${ }^{7}$ prévias e pendem sobre suas vestes. Em ocasiões cerimoniais, grandes vestes são alongadas para ocultar as duas pernas da pessoa em exibição por uma única extensa cobertura.

Seja o homem um doador ou receptor ou um dos visitantes cujo interesse no destino das conchas é mais indireto, ao olhar para a concha ele está olhando uma versão transformada de si. Convencionalmente falando, contudo, são os receptores das dádivas que são marcados como "os espectadores”. Os doadores estão em exibição para esses parceiros receptivos, essas testemunhas que irão depois levar as conchas (e os porcos) doadas para as casas dos homens. Consequentemente, os receptores não olham para imagens refletidas de si mesmos, mas para o outro lado de si mesmos: o corpo estendido (a fileira de conchas) dos doadores. o que é replicado em cada figura é a capacidade de trazer à tona tal extensão. Se cada concha é tal figura, também o é o espectador na fotografia; mas, enquanto sua talha omak e sua veste pendendo da cabeça aumentada são como a talha e o suporte da concha arredondada, sua extensão não está contida no que o(a) observador(a) veria como sua figura individual. o espectador é uma pessoa que se move em/através de relações com outros. Do mesmo modo como as conchas foram trazidas e serão levadas, sua extensão corporal repousa primeiramente na sua presença e, em segundo lugar, em sua vista. Verdadeira para todos os espectadores, essa extensão é condensada, abstraída e miniaturizada para os receptores das dádivas como o objeto explícito dos esforços dos doadores. São os receptores que estão obrigados a receber as dádivas.

Os doadores acomodaram as conchas em seu próprio terreno cerimonial, em frente a uma das casas dos homens. Os receptores saíram de suas casas em territórios distantes e vieram para terreno aberto, mobilizados pela promessa de conchas. Estando presentes e lançando olhares fixos às conchas, os receptores estendem o corpo da casa dos homens: o que eles "veem" é o que eles geraram a partir dos corpos de outros homens. Se fosse para tornar explícito para Hagen o que outros habitantes das Terras Altas abstraem em termos de gênero, os receptores feminilizados se masculinizariam elicitando dádivas e destacando-as dos doadores. Se assim fosse, o que seria miniaturizado no espetáculo se tornaria a possibilidade procriadora da diferença de gênero.

7. "Transformações de conchas" é um modo comum, na literatura antropológica sobre a Melanésia, de se referir a "pagamentos" feitos em conchas, como aqueles que ocorrem entre clãs maternos e paternos em decorrência de uma morte. Transformação de conchas se refere também ao processo em que a pessoa falecida e suas relações são objetificadas na forma de conchas (também na forma de taro - tipo de inhame - e porcos) e redistribuídas, tornando possível que novas relações sejam criadas. [N.T.] 
Isso são especulações. Todavia, suponha, como Wagner (1991) sugeriu, que a socialidade melanésia implique que pessoas sejam percebidas fractalmente ${ }^{8}$. Ou seja, na medida em que pessoas são imaginadas como entidades com relações integrais a elas, tais pessoas não podem ser pensadas por números inteiros, seja como unidades completas ou partes de um todo. Pessoas agem como se tivessem uma dimensionalidade fractal: não importa o quanto elas são divididas ou multiplicadas, pessoas e relações permanecem em proporção uma a outra, sempre mantendo sua escala. De fato, pessoas podem apenas existir divididas ou multiplicadas (por relações). É como se suas relações fossem também elas próprias. Não há razão, é claro, pela qual a pessoa fractal assim concebida seja visível para antropólogas e antropólogos. Ainda que fosse, com o que ela deveria se parecer?

As antropólogas e os antropólogos estariam à procura de uma figura que mantenha sua complexidade por meio de todas as escalas de diminuição e engrandecimento (cf. Wagner 1991, 172). o que mantém sua forma (complexa) nessas performances de Hagen é a redutibilidade do corpo: toda aparição manifesta sua redução de uma composição dual ou múltipla para o lado único que ela inevitavelmente apresenta para o mundo, pois o corpo estendido contém os elementos de sua redução, assim como poderíamos dizer que, separando-a em seus elementos, uma relação é tornada visível. o que é formado de múltiplas relações decompõe-se na entidade que busca relações com outros.

Redutibilidade é, portanto, a capacidade de ser efetivo, isto é, de procriar, gerar um produto que é também um corpo, efetuar "uma" relação. Se a capacidade repousa no futuro, ela também repousa no passado. Então, a pessoa fractal aparece na efetividade daquelas relações integrais a ela e, portanto, sempre como uma instanciação de si mesma. Agora, se as pessoas podem transformar relações completas em relações que requerem ser completadas, um modo de estar completado é ser visto por outros. Isso significa, primeiro, que a pessoa só é "vista" como uma extensão (partível) de si. Isso quer dizer, em segundo lugar, que ela é somente "vista" de um lado, pois o outro lado da (uma) pessoa é o (outra pessoa do) elicitador que evoca e completa a relação. E isso significa, em terceiro lugar, que tudo que alguém vê de si é seu próprio outro lado. Nesse mundo, pessoas contemplam os efeitos de suas extensões.

8. O contexto é a reflexão de Wagner acerca do tipo de antinomia indivíduos/sociedade que antropólogas(os) convencionalmente trouxeram para as análises dos regimes de Big Men nas Terras Altas da Papua-Nova Guiné, incitadas pela contra-figura do Great Man dos Baruya de Maurice Godelier. A ideia de indivíduos de algum modo agregados em sociedade contém uma matemática implícita que Wagner desvela por meio de outra metáfora matemática (fractais como conceitualizados na teoria do caos). 
Esse não é o lugar que a fotógrafa habita. Ela pertence a um mundo onde se pensa que é possível ver sem que se tenha um efeito. Ela também pertence a um mundo que entende semelhança como uma cópia, ou imagem como representação, que inspeciona fotografias e infindavelmente compara gráficos ${ }^{9}$. De fato, ela não teria olhado de novo essa fotografia em particular se não tivesse ficado tão intrigada pelos gráficos computadorizados da geometria fractal. Todavia, sacar replicações da fotografia, ver a mesma forma em toda forma, fazer conexões visuais entre entidades que são todas partes de uma única imagem, está longe da atividade procriadora na qual, em Hagen, seu efeito deve repousar. Lá, efetividade tem gênero: ela reside na maneira pela qual as pessoas extraem uma forma a partir de outra. Cada forma é separada de outra no processo, como receptores são separados de doadores. Duas pessoas, mas uma figura: o corpo de um deles é também o corpo do outro.

Nós poderíamos imaginar isso como a figura de um corpo cujos órgãos estão distribuídos entre pessoas (muito como euro-americanos pensam a sociedade, sua própria miniaturização da socialidade, quando eles a imaginam como vários papéis distribuídos entre indivíduos), pois ser efetivo é testemunhar o impacto - pela visão ou, diga-se, pelo chute - do corpo de alguém sobre outro. Mas, nesse modo de imaginar melanésio, o corpo que é visto ou chutado já é apenas "metade" da figura; os órgãos elicitadores estão localizados na outra metade. Portanto, seria apenas um olho que "vê" uma só perna.

\section{REFERÊNCIAS BIBLIOGRÁFICAS}

Biersack, Aletta. 1990. Histories in the making: Paiela and historical anthropology. History and Anthropology, vol. 5: 63-85.

Biersack, Aletta. 1991. Prisoners of time: millenarian praxis in a Melanesian valley. In Clio in Oceania: towards a historical anthropology, Aletta Biersack. Washington: Smithsonian Institution.

Clark, Jeffrey. 1991. Pearshell symbolism in highlands Papua New Guinea, with particular reference to the wire people of the Southern Highlands Province. Oceania, v. 61, n. 4: 309-339.

Forge, Anthony. 1965. Art and environment in the Sepik. Proceedings of the Royal Anthropological Institute of Great Britain and Ireland, n. 1965: 23-31.

9. Sobre o compromisso moderno com a mimesis, ver Taussig (1922). Em contrapartida, Don Kulick e Margaret Willson (1994) descrevem como aldeões Gapun, quando veem filmes, tentam fazê-los "funcionar" para (ter um efeito sobre) eles. 
Forge, Anthony. 1970. Learning to see in New Guinea. In Socialization: the approach from social anthropology, Philip Mayer. London: Tavistock Public.

Hanson, Allan and Louise Hanson. 1990. The eye of the beholder: a short history of the study of Maori art. In Art and identity in Oceania, Allan Hanson e Louise Hanson. Honolulu: University of Hawaii.

Jackson, Michael. 1972. Aspects of symbolism and composition in Maori art. Bijdragen tot de Taal-, Land- en Volkenkunde, vol. 128: 33-80.

Kulick, Don and Margaret Willson. 1994. Subjugating the gaze and subverting the narrative in a Papua New Guinean swamp. Visual Anthropology Review, vol. 10, n. 2: 113.

Mackenzie, Maureen. 1991. Androgynous objects: string bags and gender in Central New Guinea. Chur: Harwood Academic.

Nichols, Bill. 1991. The ethnographer's tale. Visual Anthropology Review, vol. 7, n. 2: 31-47.

Schwimmer, Eric. 1990. The anthropology of the ritual arts. In Art and identity in Oceania, ed. Allan Hanson e Louise Hanson

Smidt, Dirk. 1990. Kominimung one-legged figures: creative process and symbolic function. In Art and identity in Oceania, ed. Allan Hanson e Louise Hanson Honolulu: University of Hawaii Press.

Strathern, Andrew. 1971. The rope of moka: big men and ceremonial exchange in Mount Hagen. Cambridge: Cambridge University Press.

Strathern, Marilyn. 1992. The mother's brother's child. In Shooting the sun: ritual and meaning in the West Sepik, ed. Bernard Juillerat Washington: Smithsonian Institution.

Taussig, Michael. 1992. Physiognomic aspects of visual worlds. Visual Anthropology Review, vol. 8, n. 1: 15-28.

Wagner, Roy. 1991. The fractal person. In Big men and great men: the personifications of power, ed. Maurice Godelier e Marilyn Strathern. Cambridge: Cambridge University.

Weiner, James F. 1991. The empty place: poetry, space, and being among the Foi of Papua New Guinea. Bloomington: Indiana University. 


\section{MARILYN STRATHERN}

Professora Emérita de Antropologia Social da Universidade de Cambridge e Presidente Vitalícia (Hon.) da UK Association of Social Anthropologists (ASA). Ela é conhecida especialmente pela obra The Gender of the Gift (1988), que faz uma crítica das teorias sobre sociedade e relações de gênero aplicadas na Melanésia, e que tem como complemento o seu outro trabalho, After Nature (1992), sobre o Reino Unido no período Thatcher.

recebido

04.07.2016

aprovado

31.08.2016 O seu livro mais recente, Before and After Gender (2016), também é um dos seus primeiros, inédito desde os anos 1970. A Papua Nova Guiné está sempre presente em suas investigações, sendo que a sua última visita a Mt Hagen foi feita em 2015. 